Article

\title{
An Analysis of the Sustainable Development of Environmental Education Provided by Museums
}

\author{
Yun-Ciao Wang ${ }^{1,2, *}$ and Shang-Chia Chiou ${ }^{1}$ \\ 1 Graduate School of Design, National Yunlin University of Science and Technology, Yunlin 64002, Taiwan; \\ chiousc@yuntech.edu.tw \\ 2 Tamsui Historical Museum, New Taipei City 25172, Taiwan \\ * Correspondence: yunciao@gmail.com
}

Received: 7 October 2018; Accepted: 2 November 2018; Published: 5 November 2018

check for updates

\begin{abstract}
Under the international initiative of environmental education and ecological conservation, promoting the public's environmental awareness is the mission and goal of the museum's environmental education. The main function of the museum is to integrate the values of local, regional, and national culture toward multifaceted management, as the museum is an important cultural carrier and a key force for informal education. Past studies have focused on environmental protection in formal educational settings, while museums in nonformal educational settings have undertaken relatively few missions to the environment, which is the motivation of this study. In the past three hundred years, nine countries, including world powers like Spain, the Netherlands, the United Kingdom, and Japan, have left their footprints in Tamsui, Taiwan, creating an important field for cross-cultural environmental education. Therefore, this study takes environmental education in the protection of Taiwan's Tamsui cultural assets as its case study, and uses gradual regression analysis as a method to explore the potential factors of audience cognition resulting from the channels of museum environmental education, and to grasp the possibility of implementation. The results show that the reliability coefficient of this study is 0.908 , and the internal consistency of the representative scale is high. The overall satisfaction with environmental education of audiences is above 4.24 in the five-level subscale. Further gradual regression analysis shows that positive and negative explanatory power can be used to examine the environmental education programs of museums. Therefore, according to data analysis, the findings can serve as a basis for promoting social environmental education goals, as well as a field for cross-cultural learning, to achieve a people-oriented sustainable development strategy.
\end{abstract}

Keywords: environmental education; audience development; sustainability; regression analysis; Tamsui

\section{Introduction}

Environmental education and sustainable-development education came into being at different times. The former was conceived in the 1960s-1970s, and the latter in the 1990s. However, both of them were put forward under the background of the worsening global environment and the deepening social crisis. With people's greater understanding of the environment and environmental issues, environmental education has expanded from the field of ecology and nature studies to a broader field, gradually bringing economic and social culture into its consideration, and attaching great importance to their inter-relationship, which is also the concern of sustainable development education. As a result, the relationship between environmental education and sustainable development education has become a hot issue [1].

Gro Harlem Brundtland is known for having chaired the Brundtland Commission that presented the Brundtland Report on sustainable development. She stated that the "environment" is where we all live, and "development" is what we all do in attempting to improve our lot within that abode. 
Learning to look beyond cultural and historical barriers is essential. Chapter 2 of the Brundtland Report defines the concept of sustainable development [2]. It is a genuine belief that the Bruntland Report constitutes a big step forward for the environmental/green movement, as environmental education aims to address and solve environmental problems. It teaches the need to understand the environment, make good use of resources, protect the natural ecological balance, and prevent or deal with environmental problems. Environmental science, ecological introduction, resource conservation, pollution prevention, and environmental impact are all important contents of environmental education, which is a kind of value education, education for all, and lifelong education [3].

The triple bottom line (otherwise noted as TBL or 3BL) is an accounting framework with three parts: social, environmental (or ecological), and financial. Some organizations have adopted the TBL framework to evaluate their performance with a broader perspective in order to create greater business value [4]. Elkington's TBL is intended to advance the goal of sustainability in business practices in which the focus of companies is extended in measuring the total cost of doing business. In effect, TBL is the idea that it is possible to run an organization in a way that not only earns financial profits, but also improves people's lives and helps the planet. The elements of the triple bottom line are referred to as "people, profits, and planet." The TBL is a concept that broadens the traditional business focus on the financial bottom line to include social and environmental considerations [5]. Therefore, from the perspective of pursuing the sustainable development of human beings, it is an effective way to reawaken the potential conscience of human beings through environmental education.

In 1975, the International Conference on Environmental Education of United Nations Educational, Scientific, and Cultural Organization (UNESCO) [6] issued the Belgrade Charter environmental education, which was divided into formal and nonformal education. It is universal, lifelong, and community-based; the concepts of value and environmental integrity are similar to those applicable to museum audiences, and cover all strata, community building and preservation of culture. Its value orientation is similar. Tilbury [7] pointed out that mounting concern over environment and development problems has greater support for an educational approach, which not only considers immediate environmental improvement as its goal, but also addresses educating for 'sustainability' in the long term. Merrivan [8] pointed out that the main function of museums is to bring together the values of local, regional, or national culture. In the same year, De Backer et al. [9] further proposed that the museum experience showed that the new museum is oriented toward diversified management and is an important cultural carrier, as well as a key dispenser of nonformal education.

Environmental crises, such as global warming and ecological destruction, are having a profound impact on human beings. Most of the specialists in various fields have devoted themselves to environmental education. In the past, many studies on environmental education focused on the protection of ecoenvironmental education in formal educational fields [10-15]. Museums, in the field of non-formal education, offer relatively few missions related to the environment. During the Western Age of Discovery period to the establishment of the Republic of China, Tamsui's location on the route relay between Nanyang and East Asia attracted attention. After nine countries' influence and its political baptism, Tamsui developed a rich natural ecological landscape and livable places; many cultural assets that witnessed past history have remained largely intact and are an important field for cross-cultural environmental education. This study takes environmental education in the protection of cultural assets as a case study to explore the environmental education channels of museums, and to predict audience perceptions of the environment. Potential factors and the possibility of implementing environmental education diversity and sustainable development are also examined. The above problem explains the motivation of this study. According to UNESCO's interpretation, in order to achieve good results in environmental education, formal and informal education (UNESCO, 1980) must be properly combined. As an important nonformal social-education institution, museums are duty-bound to promote environmental education in society.

Shiang [16] indicates that museums promote the idea of environmental education by means of activity planning and design, guided tours, and so forth; carrying out their mission of environmental 
education counts on the professional competencies of educators. In order to ensure the achievement of environmental education, the museum carries the heavy responsibility of social education and plays an important role in social environmental education. Museums play an important role in nonformal environment education because of their professional manpower, equipment, and original work orientation requirements. Their functional direction includes: information propagation, personnel training, and research development. The related educational plan includes: environmental ethics, environmental management, interrelations, population and quality of life, and resource conservation. In addition to attracting audiences to their museum and participating in special study activities, seeking reference services, and other activities, museum officials can also make use of field visits outside the museum, as well as onsite observations, lectures, and knowledge-construction activities to promote an understanding of the environment. They can also inspire more people to love the environment and take actions to protect it [17]. Museums use displays, collections, and environmental and other factors to achieve a professional level, and then convey knowledge to audiences, hoping to achieve the benefits of education. Recently, educational institutions have realized that museums are ideal educational settings that can support active learning [18]. Studies in the field of outdoor education also conclude that such learning environments could positively influence students' knowledge, attitudes, interests, or motivation [19-21].

This study examines the relevant literature to list key factors affecting the sustainable development of environmental education. The goal is to assess audiences' satisfaction with museums as environmental education channels. A questionnaire was used to indicate the audience's background, which uses virtual hypotheses to explore audiences' needs, as well as hidden intrinsic factors, in exploring ways to improve the total operations. The purposes of this study are as follows:

1. Taking the museum as the venue for nonformal environmental education, with audience satisfaction transformed into a field where the audience acquires knowledge outside of school education, and determining how to strengthen the environmental significance of the museum as a global community. The means to extend the possibility of sustainable development are also discussed.

2. This study takes audience background data as an independent variable, and the problem of museum environmental education as a dependent variable, adopts a gradual regression analysis, and cross-correlation and correlations to estimate the audience's demands and expectations for environmental education, and to use the results for revising museum strategy. Achieving people-oriented care, a positive environmental attitude and a sense of an environmental education mission expresses a consensus of the museum's goals.

\section{Related Works}

\subsection{Museum Environmental Education}

Environmental education presented by museums is collaborative in nature, and appealing to visitors is closely linked to the content of this research [22]. Slater [23] pointed out that audience motivation to visit a museum includes escapism, learning, social interaction, and family. From the perspective of design pedagogy to review museums, exhibitions and social activities extend the expected research into the public sphere and propose the issue of social innovation. The competing narratives of past interpretations and displays of V and A's South Asian collections explained how to expound on imperial vision through artifacts, products, and the past and future of cultural traditions $[24,25]$. Heritage-related educational activities reflect the identity of humanity. In this sense, the museum becomes a welcoming place through different educational dimensions [26].

"Radical Museology" shows that the crucial task of museum education with regard to cultural values is urgent. Environmental education of museums is a collective expression of what we consider to be important. It is a space that reflects and debates our values [27], and internalizes our social and cultural contexts [28]. Di Pietro et al. [29] concluded that, in order to become sustainable, 
museums should pay attention to audiences and their internal diversity. Lucchi [30] showed that the environmental education of a museum usually adopts storytelling in the framework of its explanations. However, the building itself of the museum is regarded as the medium of space narration, especially historical time. For the museum-visit experience, the environmental museum as a whole is a manifestation of space and cognition.

The educational process comprises overall environmental education. It should be centered on realistic issues and have the characteristic of technology integration. It should aim at establishing values dedicated to social welfare and concern for human heritage. Its main focus should be to impress learners and actively engage them, as well as combine concern topics now and in the future. Creating knowledge and understanding through science equips us with the ability to find solutions to today's economic, social, and environmental challenges and to achieve sustainable development [31].

\subsection{Satisfaction}

The current understanding of satisfaction mainly originated from the concept of audience satisfaction put forward by Cardozo in 1965. In recent years, consumer-oriented service has proven to be the best policy, which means that managers must prioritize the demands of, and respond to, consumer needs [32] by providing the services that their customers desire [33-35].

Quality and satisfaction provide an affirmative reason for customers to repeatedly purchase products and recommend products to others; quality and satisfaction are established by demonstrating that customers' behavioral intentions are significantly influenced by the relationship between quality and satisfaction [33-35]. Deming and Edwards [36] identified quality as the most economical product in the most economical way. Goetsch and Davis [37] argue that quality is also about intangible services, people, processes, and the environment. Garvin [38] summarized various claims that quality is the degree to which a product meets consumer evaluation, i.e., quality is judged by the user as "fitness for use". Juran [39] divided consumer quality into five parts:

(1) Internal qualities: customers cannot see quality.

(2) Hardware quality: customers can see hardware quality.

(3) Software quality: customers experience and see software quality.

(4) Time promptness: service time and speed.

(5) Psychological qualities: courtesy of staff response and hospitality is cordial.

Consumer behavior is a process by which consumers decide whether or not to consume, and when, where, and from whom to buy a product or service. People often stick to internal ideals or preset goals prior to spending consideration [40]. The expectations of the agencies or enterprises in preplanning, and the differences with the audience's actual feelings make it possible to measure their willingness in the audience research approach. This is usually measured by audience-satisfaction scales; satisfaction is a general concept as well as a museum visitor's final perception of the visit. Coverage may include a summation of all the perceived facets of a service or product, or their overall assessment.

\subsection{Tamsui}

The local development strategy of Taiwan's New Taipei City Government is to set up a museum as a local cultural-development center in accordance with the local characteristics. The Tamsui Historical Museum (hereinafter referred to as Tamsui Museum), as its name implies, is a museum set up on the theme of Tamsui.

In the great voyages of the 17th century, sea power states sent expeditions to the Far East. Taiwan's Tamsui is located at the juncture of maritime-power competition in the route relay between Nanyang and East Asia. Tamsui has a wealth of natural ecological landscape environments and livable places. Three hundred years, through tariffs and commercial port civilization, military strategy, and foreign colonialism, as well as traditional Taiwanese living in settlements in Tamsui, have resulted in the rich heritage of Tamsui culture at the nexus of diverse humanities, with a natural fusion of 
valleys and forest landscapes [41]. Local cultural heritage is both a source and evidence of the local history and changing identity of a place, as well as a resource [42].

In 2003, the Ministry of Culture announced "Fort San Domingo and Surrounding Historical Buildings, Tamsui", as one of 12 potential areas in Taiwan for development. Fort San Domingo is located in the heart of the core area. River port cities are of great importance to Taiwan's urban development. Geographers have grouped human settlements in accordance with their locations, giving rise to the categories of port towns, inland towns, and hillside towns. As hubs for social interaction and trade, riverside settlements were closely connected to urban development. Tamsui, in particular, was transformed by its proximity to water transportation. The spatial and urban development of early human settlements in Taiwan can be researched by studying the history of Tamsui [41-43]. As Lüko and Kollarics [44] point out, in order to achieve the sustainable development of a community, people must rethink their attitudes toward the environment and environmental education to change their perspectives and actions. Therefore, environmental education for adults, especially local residents, is crucial, such as in the removal of invasive species to provide practical benefits. This study has its own particularity, taking the Tamsui City in Taiwan as a place of great cultural assets. The sustainable management of cultural attractions has significant pragmatic benefits.

\subsection{Current Research}

Abacı and Kamaraj [18] regard taking students to the museum as an environmental educational field trip; students' various educational techniques in the museum were tested, and the knowledge construction before and after the visit was compared. The findings show that museum education programs designed with different educational approaches provide students with cognitive learning and multiperspective recognition, and that it is possible to gain knowledge through special education programs in environmental museums. Ruso and Topdal [45] posit the importance of using a theatrical approach to museum teaching, linking schools, societies, and museums while emphasizing the effectiveness and diversity of a museum environment education.

In terms of the sustainable management of museums, quality refers to the overall audience impression of the relative superiority of products or services and their performance compared to competing products or services. For a long time, the quality and satisfaction of products or services have been regarded as the keys for businesses to create positive purchase intentions in their clients [39,46,47]. The prime aim of Frangos et al. [48] was to determine the predictors of the possibility of sustainable operation for tourists visiting destinations in Athens, the capital of Greece. Their study used multinomial logistic regression of tourist visits to explore the factors affecting Athenian visitors, and discover the problems of potential visitors. The questionnaire was designed to attract visitors by noting an important variable: impressing tourists with the historical monuments and natural environment of Athens.

The above studies clearly show that research on education acquired from museums is not a new approach $[18,45,49]$. Determining how to overcome resistance and lead residents to participate in learning is an important challenge for community environmental education [28]. Undoubtedly, researchers in different fields have taken a variety of perspectives to understand the key variables that enhance audience instruction [20,47,50]. Based on the literature (as shown in Table 1), this study classifies seven facets of the museum as an environmental educational channel: Guided Tours and Guidelines (GTG), Museum Environment and Comfort (MEC), Exhibitions and Contents (EC), Visiting Routes (VR), Information Center and Service Staff (ICSS), Education Promotion and Publicity (EPP), and Museum Educational Overall Satisfaction (MEOS). This study trusts that, in the process of audience visits, the detection of variables from the guides, service personnel, or the people accessing facilities and equipment can explain the needs and depth of the museum's expectations. This century, museums can become the focus of human-experience inheritance, study, reflection, and life leisure. 
Table 1. Summary of related museum research's seven facets of environmental education.

\begin{tabular}{|c|c|c|}
\hline $\begin{array}{l}\text { The Orientation of Museum } \\
\text { Environmental Education }\end{array}$ & Content & References \\
\hline $\begin{array}{l}\text { Guided Tours and } \\
\text { Guidelines (GTG) }\end{array}$ & $\begin{array}{l}\text { To achieve sustainable development of the community, we believe that residents' attitudes towards environmental } \\
\text { education must solve the problems of the audience. The museum starts from a professional perspective to meet the } \\
\text { needs of the audience in order to change their views and actions. The museum's guide and explanations provide } \\
\text { an opportunity to interact with each other, allowing the audience to have knowledge and good experience after visiting. }\end{array}$ & {$[16,18,30,40,44,45]$} \\
\hline $\begin{array}{l}\text { Museum Environment and } \\
\text { Comfort (MEC) }\end{array}$ & $\begin{array}{c}\text { Preventive maintenance of various items in museum buildings or the environment, temperature control, etc. are } \\
\text { all important environmental education channels for museum visitors. Museum education usually uses } \\
\text { storytelling in its interpretation framework, and museum architecture itself is seen as a medium for spatial } \\
\text { narrative, especially historical and spatial expressions. }\end{array}$ & {$[30,47]$} \\
\hline $\begin{array}{l}\text { Exhibitions and } \\
\text { Contents (EC) }\end{array}$ & $\begin{array}{l}\text { From the perspective of design environmental education, the exhibition of museum functions and social activities } \\
\text { provide the inheritance of past artifacts and modernity, disseminate knowledge to the audience, and propose } \\
\text { a space for social innovation. }\end{array}$ & {$[16,23,24,26,31,34]$} \\
\hline Visiting Routes (VR) & $\begin{array}{l}\text { When audiences visit the museum, the dynamic planning will affect the audiences' perception and the advantages and } \\
\text { disadvantages of learning; that is, the concept of extending from the main building to the public space. }\end{array}$ & {$[23,30,38]$} \\
\hline $\begin{array}{l}\text { Information Center and } \\
\text { Service Staff (ICSS) }\end{array}$ & $\begin{array}{l}\text { The quality of museum environmental education is not only the quality of the cultural relics, but also the } \\
\text { intangible services, personnel, processes, and environment. In response to the improvement of } \\
\text { tourists' knowledge and leisure style, the museums must be in the perspective of audiences and meet the service } \\
\text { type of the audience's needs. Therefore, the consultation center can interact with the audience, and the } \\
\text { satisfaction of the service staff is also the reason for the visit again. }\end{array}$ & {$[37,38,40,46,47]$} \\
\hline $\begin{array}{l}\text { Education Promotion and } \\
\text { Publicity (EPP) }\end{array}$ & $\begin{array}{l}\text { The key task of museum environmental education in cultural value is urgent, and it is also the collective } \\
\text { expression of the culture. It is a space that reflects and debates our values; therefore, the museum handles various } \\
\text { educational activities to propagate the mission of the museum. }\end{array}$ & {$[16,26,28,31]$} \\
\hline $\begin{array}{l}\text { Museum Educational Overall } \\
\text { Satisfaction (MEOS) }\end{array}$ & $\begin{array}{l}\text { In addition to the learning process, education is also the integration of the overall environmental education; } \\
\text { this case study of the heritage education action, mainly in the possibility of reflecting on the identity of the } \\
\text { person, the museum through the different educational thinking to support the open attitude towards people, } \\
\text { the museum is formed A generally recognized place. }\end{array}$ & {$[8,22,26,31,35,46,47]$} \\
\hline
\end{tabular}


Overall, this study explores the relationships of the satisfaction, intrinsic quality, and behavioral intentions of visitors regarding the museum's environmental education. This study explains environmental education via a macro view and uses gradual regression from the audience background variables applied in the cultural field. It can be said that new attempts and practices are also expected to enhance community museums as important channels for environmental education. Audiences can look forward to the museum as a multicultural practice field, and the museum can subtly influence the audience with visible and invisible approaches. To strengthen the delicate relationship between museum and audience, a platform for environmental education can be set up.

\section{Method}

\subsection{Questionnaire Survey}

From the descriptions of Table 1, this study first explores the predictions of environmental education of museum satisfaction according to audiences' background and willingness-to-pay variables. Among them, the seven variables of satisfaction are used as predictors and to explore the museum's causal relationship with environmental educational channel satisfaction by multiple gradual regressions. The quantitative survey content is shown in Table 2.

Table 2. Quantitative survey content.

\begin{tabular}{lccc}
\hline \multicolumn{1}{c}{ Item } & Content & Measurement Standards & Virtual Assumptions \\
\hline $\begin{array}{l}\text { Actual Visit } \\
\text { Experience }\end{array}$ & Traffic flow; overall satisfaction & $\begin{array}{c}\text { Likert's five-point scale } \\
\text { design scale }\end{array}$ & Dependent Variable \\
\hline $\begin{array}{c}\text { Professional } \\
\text { Satisfaction }\end{array}$ & $\begin{array}{c}\text { Exhibition, navigation, promotional } \\
\text { material satisfaction }\end{array}$ & $\begin{array}{c}\text { Likert's five-point scale } \\
\text { design scale }\end{array}$ & Dependent Variable \\
\hline $\begin{array}{c}\text { Personal } \\
\text { Background }\end{array}$ & $\begin{array}{c}\text { Gender, age, education, marital status, } \\
\text { occupation, monthly salary, residence, } \\
\text { with which peers, visitors, number of visits, } \\
\text { admission fee, etc. }\end{array}$ & $\begin{array}{c}\text { Survey is multiple-choice; } \\
\text { the rest are single-option }\end{array}$ & Independent Variable \\
\hline $\begin{array}{l}\text { Willingness } \\
\text { to Pay }\end{array}$ & willingness to pay; paid value & $\begin{array}{c}\text { Condition } \\
\text { Assessment Method }\end{array}$ & Independent Variable \\
\hline $\begin{array}{l}\text { Remark: Likert's five-point scale design scale as a measure of satisfaction with the order of 1 to 5 points; the options } \\
\text { are: very unsatisfied, dissatisfied, neutral, satisfied, very satisfied with the five rating scales, respectively. }\end{array}$
\end{tabular}

\subsection{Research Architecture}

According to sustainable development education formulated by the commission on sustainable development in the United States, one of the key principles is participation. Therefore, determining how to attract audiences to visit museums to become involved in environmental education is an interesting issue. As mentioned above: audience satisfaction is a key factor for constructing the sustainable development of environment education. Therefore, we aim to construct the architecture of null hypothesis mode in this study to realize audience needs. In this study, the background of audiences and the assessment data on fee charging are the null hypotheses of the independent variables; the environmental education satisfaction of the museum as the channel is the dependent variable, which includes the hardware and software of the buildings, research, activities, and services. In this study, guidance arrangement, environmental comfort, exhibition planning and content, visiting line, staff and consulting services, educational and promotional activities, and the overall environmental education of the museum are seven factors serving as dependent variables to construct a gradual regression analysis model. The explanatory significance of regression models is dependent on different virtual assumptions (as shown in Figure 1). 


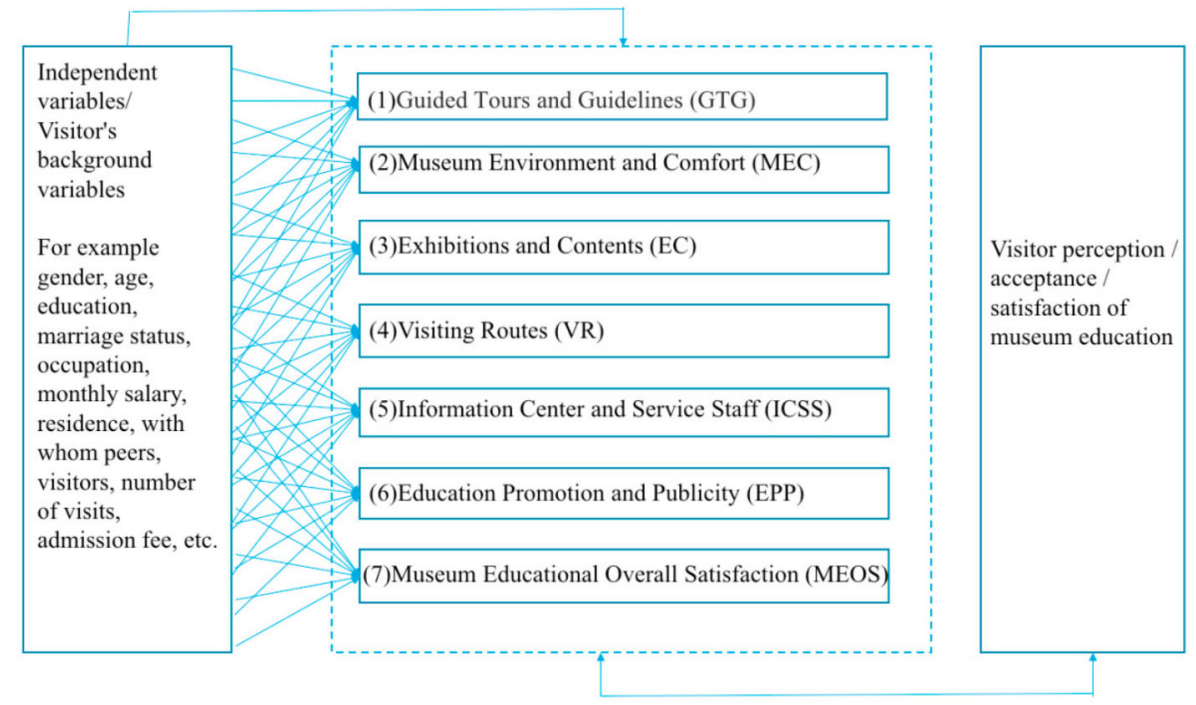

Figure 1. Architecture of null hypothesis of this study.

\subsection{Research Flowchart}

In Figure 2, we show the flowchart of the gradual regression analysis of this study.

(1) Discrete or discontinuous variables in the background are used as dummy variables serving as independent variables for this study. An independent variable is a category variable; we can construct these categories one by one into virtual variables, for example: gender, age, education, marital status, occupation, monthly salary, residence, with which peers, visitors, number of visits, and admission fee.

(2) Using the seven consecutive variables of satisfaction as the dependent variables (as shown in Table 3), we used multivariate analysis to examine whether each of the variables prepared for inclusion in the regression analysis complied with the basic assumptions of linear regression analysis.

(3) Significant impact factors were obtained by using gradual regression analysis, which is usually the ratio of two numbers, with each figure estimating a variance. The causes of these significant influencing factors, and whether the regression coefficient reaches significance were explored herein.

Table 3. Satisfaction facets of seven consecutive variables.

\begin{tabular}{lc}
\hline \multicolumn{2}{c}{ Dependent Variables (Museum Education Satisfaction) } \\
\hline Dependent variable (1) & Guided Tours and Guidelines (GTG) \\
Dependent variable (2) & Museum Environment and Comfort (MEC) \\
Dependent variable (3) & Exhibitions and Contents (EC) \\
Dependent variable (4) & Visiting Routes (VR) \\
Dependent variable (5) & Information Center and Service Staff (ICSS) \\
Dependent variable (6) & Education Promotion and Publicity (EPP) \\
Dependent variable (7) & Museum Educational Overall Satisfaction (MEOS) \\
\hline
\end{tabular}




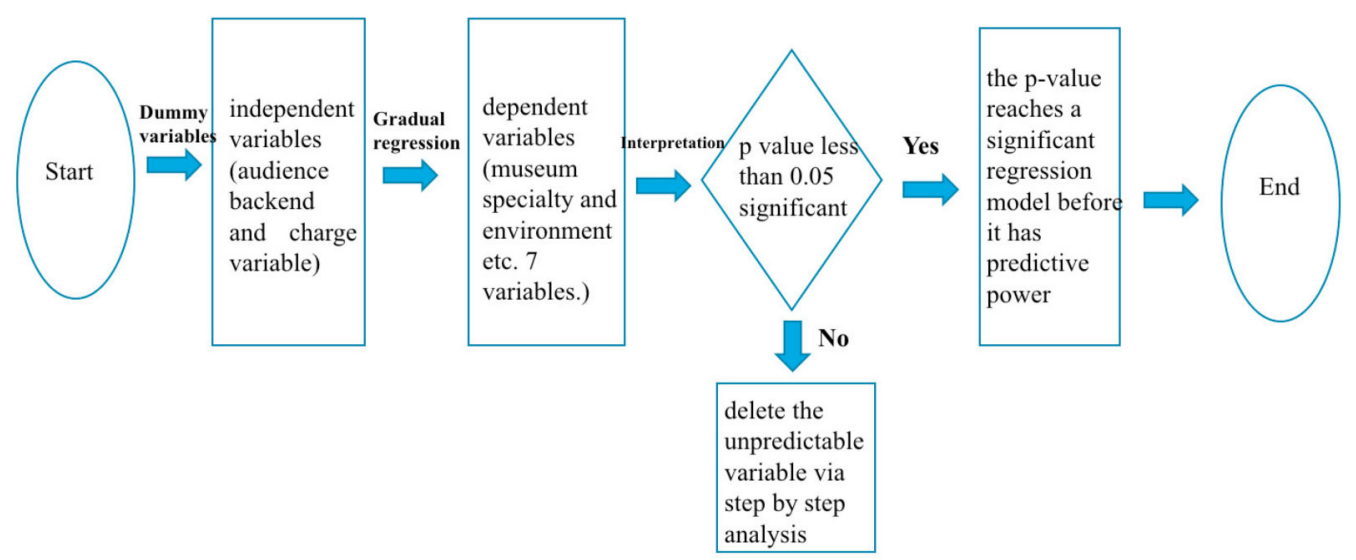

Figure 2. Flowchart of the gradual regression analysis of this study.

\subsection{Multivariate Regression Analysis}

Multivariate regression analysis [51] was used to explore the relationships between multiple predictors and one dependent variable. In this study, we used a multiple gradual regression model to explore the relationship between the background variable of audience $(x)$ and the audience satisfaction with environmental education of museum as a dependent variable $(y)$, and established a regression model to predict the relationship between the variables' $(y)$ meanings. Multivariate linear regression uses two or more independent variables $(x)$ to predict the dependent variable $(y)$, step by step.

(1) Null hypothesis:

Discrete or discontinuous variables in the background were used as dummy variables to serve as independent variables for this study.

In exploring whether or not the $\beta$ coefficient of the individual argument is 0 , if the coefficient is not 0 , the argument is explanatory power (a total of $k$ times to do the test).

Alternative hypothesis:

$$
H_{0}: \beta_{i}=0(i=1,2, \ldots, k)
$$

Alternative hypothesis

$$
H a: \beta_{i} \neq 0(i=1,2, \ldots, k)
$$

(2) The original model:

The audience of environmental education of museum satisfaction includes seven consecutive variables as the study's variables.

In multivariate linear regression, the dependent variable must be a continuous variable; multivariate analysis is used to examine if a variable meets the basic assumptions of the multivariate regression analysis. The regression model was selected and the resulting parameter estimates and goodness of fit were evaluated; $\varepsilon$ is the errors:

$$
Y=\beta_{0}+\beta_{1} x_{1}+\beta_{2} x_{2}+\ldots+\beta_{k} x_{k}+\varepsilon
$$

where $\beta_{0}$ is the intercept of regression model; and $\beta_{1} \ldots \beta_{k}$ are the unknown and estimated regression coefficients, respectively.

The estimated formula is:

$$
\hat{Y}=\hat{\beta}_{0}+\hat{\beta}_{1} x_{1}+\hat{\beta}_{2} x_{2}+\ldots+\hat{\beta}_{k} x_{k}
$$

(3) Significance test ( $F$ test): 
The F-test statistics can be used in simple linear regression to assess the overall fit of the model.

$$
F=\text { statest tistics for regression }=M S R / M S E \text {, }
$$

where $M S R=$ Mean Square Regression, $M S E=$ Mean Square Error; $F$ has $d f_{S S R}$ for the numerator and $d f_{S S E}$ for the denominator.

The null and alternative hypotheses for simple linear regression for the $F$-test statistics are:

$H_{\mathrm{o}}: b_{1}=0$; where $b_{1}$ is the coefficient for $x$ (i.e., the slope of $x$ )

$H_{\mathrm{a}}: b_{1}$ is not 0

$p$-value: the probability that random variable $F>$ the probability value of the test statistics. This value is found by using an $F$ table where $F$ has $d f_{S S R}$ for the numerator and $d f_{S S E}$ for the denominator. $M S R=$ Sum of Square Regression/(Regression Square of Freedom):

$$
F=\frac{M S R}{M S E}
$$

The regression analysis results of the $F$ test are significant ( $p$ value); when the coefficient is not 0 , the regression model is predictive; gradual regression analysis of the first decision deletes nonexplanatory power variables ( $p$ value is usually greater than 0.05 ).

\section{(4) Determination coefficient}

The aim was to explore the causes of the significant impact factors and derive research recommendations. In general, the coefficient of determination is greater than 0.5 , which is the null hypothesis of a nonexplanatory power. The $R^{2}$ for this pattern in the population is not zero or, since at least one independent variable has explanatory power, the meaning of $R^{2}$ (or included adjusted $R^{2}$ in the adjusted number of independent variables) is how much all independent variables explain the amount of variation in the ratio of the strains. The larger the percentage that can be explained in the total variation of the $R^{2}$ regression model is, the better the fitness of the regression model:

$$
R^{2}=\frac{S S R}{S S T}=1-\frac{S S E}{S S T}
$$

\section{Data Analysis}

In this paper, we used SPSS version 22 [52] of the social science statistics as the data statistical analysis tool to explore whether the independent and dependent variables have explanatory power, based on gradual regression analysis. A quantitative test survey was conducted from 1 August 2017 to 10 September 2017, for a total of 40 days. The survey was conducted via 666 questionnaires in Fort San Domingo [53]. During the survey, there were 64,680 visitors in Fort San Domingo. The mathematical theoretical basis of the sampling theory in Equation (1) shows a population of $\mathrm{N}=64,680$ with a sample size of $n=666$, for a total of 645 valid questionnaires with a sampling rate of $0.99 \%$, which is equivalent to one sample of participants in a sample of $95 \%$ confidence level. It is equivalent to a sample of one-hundred visitors, and reliability is the measure of the error degree and the degree of consistency of the test results. The reliability coefficient of this study is 0.908 . The higher the Cronbach's alpha coefficient is, the higher the internal consistency of the representative scales; the alpha value of the main facet being greater than 0.8 is ideal.

\subsection{Audience Background Investigation Information}

The following detail the main audience background investigation information.

(1) Overview of gender: Subjects were mostly females, 397, comprising 61.6\%, and 248 males, comprising $38.4 \%$. 
(2) Overview of age composition: Subjects aged from 21 to 30 totaled $166(25.7 \%) ; 31$ to 40 totaled 148 people (22.9\%); 20 years and below totaled 69 persons $(10.7 \%)$.

(3) Overview of educational composition: The degree of academic education was mainly college degree or above, with a total of $646(56.4 \%)$, followed by high-school education, which was 206 (18.0\%).

(4) Overview of marital status: Most of the subjects were married with children, 307 (47.6\%), followed by singles, totaling $256(39.7 \%)$.

(5) Overview of employment: A total of 167 were in the business-service industry (25.9\%), followed by 151 students $(23.4 \%)$.

(6) Overview of monthly income: Most people, 206 (31.9\%), had a monthly income of 39,999 NTD, followed by 199 persons (30.9\%) with no income.

(7) Overview of demographics: Mostly Taipei citizens, totaling 166 (25.7\%).

Descriptive analysis of the relevant audience background variables is shown in Table 4. In addition, the seven facets of the museum as an environmental educational channel were GTG, MEC, EC, VR, ICSS, EPP, and MEOS. In the satisfaction analysis, the mean ICSS of the highest mean was 4.52, and the average of EC 4.24 was the lowest of the seven facets. We show the satisfaction analysis of the seven facets of the museum for environmental education channel. In Table 5, the results show that overall satisfaction was generally good in the sampling of the Tamsui Historical Museum, so the effectiveness of environmental education can be used as a reference case.

Table 4. Descriptive analysis of audience background variables.

\begin{tabular}{|c|c|c|c|}
\hline Measure & Category & Frequency $(N=645)$ & Percent \\
\hline \multirow[t]{2}{*}{ Gender } & Male & 248 & 38.4 \\
\hline & Female & 397 & 61.6 \\
\hline \multirow[t]{6}{*}{ Age } & below 20 & 69 & 10.7 \\
\hline & $21 \sim 30$ & 166 & 25.7 \\
\hline & $31 \sim 40$ & 148 & 22.9 \\
\hline & $41 \sim 50$ & 127 & 19.7 \\
\hline & Above 51 & 112 & 17.4 \\
\hline & 65 or above & 23 & 3.6 \\
\hline \multirow[t]{4}{*}{ Education } & Junior high school & 29 & 4.5 \\
\hline & Senior high school & 110 & 17.1 \\
\hline & Undergraduate & 410 & 63.6 \\
\hline & Graduate & 96 & 14.9 \\
\hline Marital & Single & 256 & 39.7 \\
\hline \multirow[t]{3}{*}{ Status } & Married, without children & 77 & 11.9 \\
\hline & Married, with children & 307 & 47.6 \\
\hline & Others & 5 & 0.8 \\
\hline \multirow[t]{9}{*}{ Occupation } & Student & 151 & 23.4 \\
\hline & Military service man & 53 & 8.2 \\
\hline & Service sector & 167 & 25.9 \\
\hline & Farmer, lumberman & 5 & 0.8 \\
\hline & Housekeeper & 51 & 7.9 \\
\hline & Professional & 115 & 17.8 \\
\hline & Retired & 55 & 8.5 \\
\hline & Between jobs & 12 & 1.9 \\
\hline & Others & 36 & 5.6 \\
\hline
\end{tabular}


Table 4. Cont.

\begin{tabular}{|c|c|c|c|}
\hline Measure & Category & Frequency $(N=645)$ & Percent \\
\hline Monthly & None & 199 & 30.9 \\
\hline \multirow[t]{3}{*}{ Salary } & Below US\$1400 & 206 & 31.9 \\
\hline & US\$1400-2700 & 187 & 29 \\
\hline & Above US\$2700 & 53 & 8.2 \\
\hline Number of & First & 278 & 43 \\
\hline \multirow[t]{2}{*}{ visits } & Second & 161 & 25 \\
\hline & Third or more & 206 & 32 \\
\hline \multirow{8}{*}{ Residence } & New Taipei City & 37 & 5.7 \\
\hline & Taipei City & 166 & 25.7 \\
\hline & Northern Taiwan & 149 & 23.1 \\
\hline & Central Taiwan & 65 & 10.1 \\
\hline & Southern Taiwan & 45 & 7 \\
\hline & Eastern Taiwan & 11 & 1.7 \\
\hline & Abroad & 81 & 12.6 \\
\hline & Tamsui & 91 & 14.1 \\
\hline With which & Alone & 21 & 3.3 \\
\hline \multirow[t]{5}{*}{ peers } & Friends or classmates & 273 & 42.3 \\
\hline & Tour group & 46 & 7.1 \\
\hline & Club & 43 & 6.7 \\
\hline & Relatives or family & 249 & 38.6 \\
\hline & Others & 13 & 2 \\
\hline \multirow[t]{4}{*}{ Visitors } & $2-4$ & 374 & 58 \\
\hline & $5-8$ & 164 & 25.4 \\
\hline & $9-19$ & 55 & 8.5 \\
\hline & Over 20 & 52 & 8.1 \\
\hline
\end{tabular}

Table 5. Satisfaction analysis of the seven facets of the museum for environmental education channel

\begin{tabular}{cccccc}
\hline Facet & Range & Minimum & Maximum & Mean & Std. Deviation \\
\hline GTG & 4 & 1 & 5 & 4.37 & 0.656 \\
MEC & 4 & 1 & 5 & 4.48 & 0.629 \\
EC & 4 & 1 & 5 & 4.24 & 0.711 \\
VR & 3 & 2 & 5 & 4.36 & 0.699 \\
ICSS & 4 & 1 & 5 & 4.52 & 0.632 \\
EPP & 3 & 2 & 5 & 4.38 & 0.644 \\
MEOS & 3 & 2 & 5 & 4.42 & 0.594 \\
\hline \multicolumn{5}{c}{ Valid N $=645}$.
\end{tabular}

\subsection{Regression Analysis Results}

This study used gradual regression analysis (Figures 1 and 2). Table 6 is a list of significant explanations (significant $<0.05$ ), including professional, military service, below 20 years old, and unemployed, which had positive explanatory power for GTG; professional had positive explanatory power for MEC; married with children has negative explanatory power for MEC; professional, below 20 years old, and military service had positive explanatory power for EC, Taipei City citizen had negative explanatory power for EC; etc. 
Table 6. Significant analysis table of gradual regression.

\begin{tabular}{|c|c|c|c|c|c|c|c|c|c|c|c|}
\hline \multirow{2}{*}{$\begin{array}{l}\text { Dependent } \\
\text { Variable } \\
\text { (Museum } \\
\text { Education } \\
\text { Satisfaction) }\end{array}$} & \multirow{2}{*}{$\begin{array}{c}\text { Significant } \\
\text { Variables of } \\
\text { Gradual } \\
\text { Regression }\end{array}$} & \multicolumn{2}{|c|}{$\begin{array}{l}\text { Unstandardized } \\
\text { Coefficients }\end{array}$} & \multirow{2}{*}{$\begin{array}{c}\begin{array}{c}\text { Standardized } \\
\text { Coefficients }\end{array} \\
\text { Beta }\end{array}$} & \multirow{2}{*}{$t$} & \multirow{2}{*}{ Sig. } & \multicolumn{3}{|c|}{ Correlations } & \multicolumn{2}{|c|}{$\begin{array}{l}\text { Collinearity } \\
\text { Statistics }\end{array}$} \\
\hline & & B & $\begin{array}{l}\text { Std. } \\
\text { Error }\end{array}$ & & & & Zero-order & Partial & Part & Tolerance & VIF \\
\hline \multirow{5}{*}{ GTG } & (Constant) & 4.267 & 0.032 & & 132.371 & 0.000 & & & & & \\
\hline & Professional & 0.307 & 0.068 & 0.179 & 4.513 & 0.000 & 0.142 & 0.176 & 0.174 & 0.944 & 1.059 \\
\hline & Military service & 0.262 & 0.094 & 0.110 & 2.783 & 0.006 & 0.071 & 0.109 & 0.108 & 0.961 & 1.040 \\
\hline & below 20 & 0.221 & 0.084 & 0.104 & 2.634 & 0.009 & 0.063 & 0.104 & 0.102 & 0.957 & 1.045 \\
\hline & Between jobs & 0.382 & 0.188 & 0.079 & 2.029 & 0.043 & 0.062 & 0.080 & 0.078 & 0.993 & 1.008 \\
\hline \multirow{3}{*}{ MEC } & (Constant) & 4.490 & 0.035 & & 128.393 & 0.000 & & & & & \\
\hline & Between jobs & 0.256 & 0.064 & 0.156 & 3.983 & 0.000 & 0.146 & 0.155 & 0.155 & 0.990 & 1.010 \\
\hline & $\begin{array}{l}\text { Married, with } \\
\text { children }\end{array}$ & -0.116 & 0.049 & -0.092 & -2.361 & 0.019 & -0.077 & -0.093 & -0.092 & 0.990 & 1.010 \\
\hline \multirow{5}{*}{ EC } & (Constant) & 4.168 & 0.038 & & 109.567 & 0.000 & & & & & \\
\hline & Professional & 0.296 & 0.073 & 0.159 & 4.026 & 0.000 & 0.123 & 0.157 & 0.155 & 0.949 & 1.053 \\
\hline & below 20 & 0.314 & 0.091 & 0.137 & 3.452 & 0.001 & 0.110 & 0.135 & 0.133 & 0.951 & 1.052 \\
\hline & $\begin{array}{l}\text { Military service } \\
\text { man }\end{array}$ & 0.249 & 0.102 & 0.096 & 2.436 & 0.015 & 0.050 & 0.096 & 0.094 & 0.955 & 1.047 \\
\hline & Taipei City & -0.141 & 0.063 & -0.087 & -2.227 & 0.026 & -0.088 & -0.088 & -0.086 & 0.980 & 1.020 \\
\hline \multirow{5}{*}{ VR } & (Constant) & 4.373 & 0.041 & & 107.950 & 0.000 & & & & & \\
\hline & Service Section & -0.241 & 0.064 & -0.151 & -3.780 & 0.000 & -0.112 & -0.148 & -0.147 & 0.938 & 1.066 \\
\hline & Retired & -0.238 & 0.099 & -0.095 & -2.405 & 0.016 & -0.078 & -0.095 & -0.093 & 0.963 & 1.038 \\
\hline & tour group & 0.281 & 0.109 & 0.103 & 2.566 & 0.011 & 0.073 & 0.101 & 0.100 & 0.926 & 1.080 \\
\hline & $\begin{array}{c}\text { relatives or } \\
\text { family members }\end{array}$ & 0.128 & 0.058 & 0.090 & 2.230 & 0.026 & 0.052 & 0.088 & 0.087 & 0.934 & 1.071 \\
\hline \multirow{3}{*}{ ICSS } & (Constant) & 4.464 & 0.029 & & 152.964 & 0.000 & & & & & \\
\hline & Professional & 0.197 & 0.065 & 0.119 & 3.011 & 0.003 & 0.104 & 0.118 & 0.118 & 0.974 & 1.027 \\
\hline & below 20 & 0.188 & 0.081 & 0.092 & 2.324 & 0.020 & 0.073 & 0.091 & 0.091 & 0.974 & 1.027 \\
\hline \multirow{6}{*}{ EPP } & (Constant) & 4.397 & 0.044 & & 99.084 & 0.000 & & & & & \\
\hline & Professional & 0.216 & 0.067 & 0.129 & 3.228 & 0.001 & 0.112 & 0.127 & 0.125 & 0.938 & 1.066 \\
\hline & $\begin{array}{c}\text { Below } 1400 \text { US } \\
\text { dollars }\end{array}$ & -0.121 & 0.055 & -0.088 & -2.210 & 0.027 & -0.110 & -0.087 & -0.085 & 0.946 & 1.057 \\
\hline & $\begin{array}{l}\text { friends or } \\
\text { classmates }\end{array}$ & -0.139 & 0.051 & -0.107 & -2.755 & 0.006 & -0.109 & -0.108 & -0.106 & 0.987 & 1.013 \\
\hline & below 20 & 0.191 & 0.084 & 0.092 & 2.283 & 0.023 & 0.071 & 0.090 & 0.088 & 0.920 & 1.087 \\
\hline & Military service & 0.202 & 0.093 & 0.086 & 2.169 & 0.030 & 0.071 & 0.086 & 0.084 & 0.944 & 1.059 \\
\hline \multirow{6}{*}{ MEOS } & (Constant) & 4.358 & 0.033 & & 133.739 & 0.000 & & & & & \\
\hline & below 20 & 0.283 & 0.076 & 0.147 & 3.719 & 0.000 & 0.125 & 0.146 & 0.143 & 0.950 & 1.052 \\
\hline & Professional & 0.193 & 0.061 & 0.124 & 3.135 & 0.002 & 0.091 & 0.123 & 0.121 & 0.948 & 1.055 \\
\hline & tour group & 0.211 & 0.089 & 0.091 & 2.365 & 0.018 & 0.097 & 0.093 & 0.091 & 0.992 & 1.008 \\
\hline & Military service & 0.192 & 0.085 & 0.089 & 2.255 & 0.025 & 0.043 & 0.089 & 0.087 & 0.954 & 1.048 \\
\hline & Taipei City & -0.119 & 0.053 & -0.087 & -2.241 & 0.025 & -0.097 & -0.088 & -0.086 & 0.976 & 1.025 \\
\hline
\end{tabular}

Results are shown in Table 7, with the independent variables of this study for gender, education, number of visits, and visitors corresponding to the dependent variables that have no explanatory power; independent variables below 20 years old hd positive explanatory power for GTG, EC, ICSS, EPP, and MEOS; military service had positive explanatory power for GTG, EC, EPP, MEOS, EC, ICSS, and EPP; MEOS variables had positive explanation; the above signifies the mode of positive explanatory power. In addition, marital status, married, and married with children for MEC, service section and retired for VR, residence in Taipei City for EC and MEOS, friends or classmates, etc., had negative explanatory power for EPP. 
Table 7. Independent variables corresponding to the dependent variables of the total tables of this study.

\begin{tabular}{|c|c|c|c|c|c|c|c|c|}
\hline & & GTG & MEC & EC & VR & ICSS & EPP & MEOS \\
\hline Gender & $\begin{array}{l}\text { Male } \\
\text { Female }\end{array}$ & & & & & & & \\
\hline Age & $\begin{array}{l}\text { below } 20 \\
21 \sim 30 \\
31 \sim 40 \\
41 \sim 50 \\
50 \sim 51 \\
\text { Above } 51\end{array}$ & $\bullet$ & & $\bullet$ & & $\bullet$ & $\bullet$ & $\bullet$ \\
\hline Education & $\begin{array}{l}\text { Junior high School } \\
\text { Senior high School } \\
\text { Undergraduate } \\
\text { Graduate }\end{array}$ & & & & & & & \\
\hline $\begin{array}{l}\text { Marital } \\
\text { Status }\end{array}$ & $\begin{array}{l}\text { Single } \\
\text { Married without children } \\
\text { Married with children }\end{array}$ & & $\times$ & & & & & \\
\hline Occupation & $\begin{array}{l}\text { Student } \\
\text { Military service man } \\
\text { Service Section } \\
\text { Farmer, lumberman, fisherman } \\
\text { Housekeeper } \\
\text { Professional } \\
\text { Retired } \\
\text { Between jobs }\end{array}$ & - & $\bullet$ & $\bullet$ & $\begin{array}{l}\times \\
\times\end{array}$ & $\bullet$ & $\bullet$ & $\bullet$ \\
\hline $\begin{array}{l}\text { Monthly } \\
\text { Salary }\end{array}$ & $\begin{array}{l}\text { None } \\
\text { Below US } \$ 1400 \\
\text { US } \$ 1400-2700 \\
\text { Above US } \$ 2700\end{array}$ & & & & & & $x$ & \\
\hline $\begin{array}{l}\text { Number of } \\
\text { visits }\end{array}$ & $\begin{array}{l}\text { First } \\
\text { Second } \\
\text { Third or more }\end{array}$ & & & & & & & \\
\hline Residence & $\begin{array}{l}\text { New Taipei City } \\
\text { Taipei City } \\
\text { Northern Taiwan } \\
\text { Central Taiwan } \\
\text { Southern Taiwan } \\
\text { Eastern Taiwan }\end{array}$ & & & $x$ & & & & $x$ \\
\hline $\begin{array}{l}\text { With whom } \\
\text { peers }\end{array}$ & $\begin{array}{l}\text { Alone } \\
\text { Friends or classmates } \\
\text { Tour group } \\
\text { Club } \\
\text { Relatives or family }\end{array}$ & & & & - & & $\times$ & • \\
\hline Visitors & $\begin{array}{l}2-4 \\
5-8 \\
9-19\end{array}$ & & & & & & & \\
\hline
\end{tabular}

Remark: “๑" positive exploratory power; “ $\times$ ” negative exploratory power.

To sum up, among the seven factors: under 20 years old, GTG, EC, ICSS, EPP, MEOS, etc., five factors had positive explanatory power. This study further verified that below 20 years old accounted for $10.7 \%$ and students accounted for $23.4 \%$ (refer to Table 4 ). According to the official website of the Tamsui Historical Museum, there are more than 6000 guided tours a year, of which nearly 50\% are academic. Students' outdoor visiting groups, including junior-, elementary-, and high-school 
and University students, mainly publicize the protection of Tamsui culture and history, and continue to conduct various monumental activities, which is also the purpose of the establishment of the Tamsui Historical Museum. Therefore, continuing to conduct these activities would result in better performance. However, because it is the museum that leads the students to visit, students are unable to independently arrange the route, and this one has no explanatory power on the route.

Professional, a self-variable, had positive explanatory power among the seven factors, including GTG, MEC, EC, ICSS, EPP, and MEOS. The Tamsui area is famous for its numerous historic sites. In the past literature discussions, the traditional residents of Taiwan live in Tamsui settlements, creating a rich Tamsui culture, and meeting a pluralistic one [53]; local cultural heritage is both a resource and evidence of changes in local history and identity. Tamsui has been built at different times by the West Dutch, Japanese, British, and Han nationalities. In addition to regular tourists, professionals also like to visit Tamsui, so it can be a key factor for the sustainable development of environmental education.

In addition, for married with children for MEC, service section and retired for VR, residence for EC and MEOS in Taipei City, and friends or classmates for EPP, museums can examine the relevance of the mission and purpose of museums. For example, in order to preserve the integrity of historic sites, it is difficult to have innovative plans for new technology and mobility arrangements. In this case, more guided tours or educational activities are needed to promote the correct conservation concept. The cultural resources in Taipei are abundant, and appreciation of culture is relatively high. Therefore, the negative explanatory power of EC and MEOS can be used as a reference for revising the operation and management of museums.

\section{Conclusions and Suggestions}

Museums have different types of presentations due to different collections. Museums of different types perform their functions according to their respective mission objectives. The collection of the Tamsui Historical Museum includes all kinds of buildings. Since the rise of environmental education in the 1970s, museums have recognized their mission to protect the environment and have pondered the role of environmental education. However, as there are many methods of environmental education, determining how to use appropriate environmental education methods to various types of museums while strengthening the characteristics of museums is indeed a problem worthy of discussion. The museum experience shows that the museum is a cultural carrier as well as an educational purveyor. This study interprets the needs of the audience from the perspective of the environmental education channel of the museum in order to realize the trend of people-oriented museums. The experimental analysis and literature analysis are as follows:

(1) Experimental analysis:

The results showed the number of population $N=64,680 ; 645$ valid scale questionnaires were sampled, and the sampling ratio was $0.99 \%$. At $95 \%$ confidence level, the reliability coefficient was 0.908 , representing the high internal consistency of the scale. Therefore, overall satisfaction was above 4.24 (in Table 5) in the five scale tests. The environmental education effectiveness of its cultural assets is one of the reference cases. In addition, in the analysis of Section 4.2, if the causal relationship between the independent and dependent variables is not obvious, the museum can continuously observe its changes. Among the seven factors, the independent variables below 20 years old and professional have significant positive explanatory powers; this is closely related to the museum's purpose, promoting the historical protection of Tamsui culture, and continuing to conduct various historical activities. Local cultural heritage is not only a resource, but also evidence of changes in local history and identity. Besides Tamsui local residents, tourists and professionals also like to visit the museum. Therefore, it can be a key factor for sustainable local development of environmental education. In view of the negative explanatory power, in order to preserve the integrity of the historic sites, it is difficult to make innovative plans for new technology and movement arrangements. It is necessary to use more guided tours or educational activities to publicize, so that audiences have 
a correct concept of preservation. The inadequate part can be used as a reference for the revision of the museum's operation and management.

(2) Literature analysis:

In this paper, the TBL concept was analyzed. As mentioned above, it consists of three parts: society, environment (or ecology), and economy.

1. "Society": the triple bottom line of society means people. This study uses the concept of museum "audience" to cover all strata, community building, and cultural protection. Its value orientation is similar. In line with the 1975 UNESCO definition of environmental education, it is universal, lifelong, and community-based, signifying the concepts of value and environmental integrity.

2. "Economy": the triple bottom line economy refers to profit; this study takes the Taiwan Tamsui Museum, a nonprofit organization, as a case study; it is an important informal social education institution. Museums have the responsibility to promote social environmental education. Apart from expressing cross-cultural and cultural equality, it is also an effective way to reconfigure it through environmental education.

3. "Environment (or ecology)": The TBL indicates environment as the planet itself. In fact, TBL's view is to operate an organization in a way that not only makes economic profit, but also improves people's lives and helps the earth by preventing or dealing with environmental problems; environmental science, ecology, conservation of resources, prevention of public hazards, and environmental impact are all important parts of environmental education, which is a value education, education for all people, lifelong education, and a good manifestation of sustainable development.

As implementation of the United Nations Environment Program (UNEP), World Conservation Union (IUCN) and World Wide Fund for Nature (WWF) [54] published Caring for the EarthA Strategy for Sustainable Living in 1991. The book proposed to establish world ethics based on people-centered and conservation-based education. The global community is made up of all living things; it integrates human society and nature. This study takes the Tamsui community museum with many cultural assets as an example to enhance the quality of visits and achieve sustainable management. In fact, audience satisfaction is a key factor for constructing the sustainable development of environment education, as this study attests.

The contributions of this study are as follows:

1. Explored the causal relationship between audiences' background variables and satisfaction, as well as the potential factors of museum environmental education at different audience levels. It can rethink the goals and practices of promoting social environmental education and serve as a research reference of the cultural-type museum.

2. Discussed the different audience views regarding the museum as an environment education channel; the findings can be used as reference for the museum management strategy, including museum audience analysis, the key factors of sustainable development, and as a field of cross-cultural learning, to achieve a people-oriented sustainable development strategy.

Because the results of this study significantly differ from each other through causal relationships between independent variables and dependent variables, both positive and negative responses can be explored in depth, while negative explanations do not necessarily lead to poor responses, especially when testing for homogeneity problems. In other words, the fault of management can be corrected in time, or inspections made as to whether or not the objectives of the museum's environmental education are consistent. This study analyzed the implicit but inconspicuous key factors by means of quantitative test questionnaires, and suggests that further indepth interviews for explanatory variables be conducted in future studies. Thus, the combination of data and implementation can help to better understand audience demand for knowledge and provide a reference for managers to revise their business strategies. 
Author Contributions: This research was conjointly designed and planned by Y.-C.W. The structure and discussion were realized by S.-C.C. The authors have read and approved the final manuscript.

Funding: This research received no external funding.

Conflicts of Interest: The authors declare no conflict of interest.

\section{References}

1. Wang, M.; Wei, D.Y.; Huo, Z.L. Environmental Education and Education for Sustainable Development. J. Beijing Norm. Univ. Soc. Sci. 2006, 3, 131-136.

2. Bruntland Report. Available online: http://mom.gov.af/Content/files/Bruntland_Report.pdf (accessed on 28 October 2018).

3. Yang, G.Z. Planning and Research on Environmental Education in Taiwan; The Environmental Protection Agency of the Executive Yuan Environmental Protection Department: Taipei, Taiwan, 1988; p. 64.

4. Slaper, T.F.; Hall, T.J. The Triple Bottom Line: What Is It and How Does It Work. Indiana Bus. Rev. 2011, 86, 4-8.

5. Elkington, J. 25 Years Ago I Coined the Phrase “Triple Bottom Line”. Here's Why It's Time to Rethink It. Harv. Bus. Rev. 2018. Available online: https://hbr.org/2018/06/25-years-ago-i-coined-the-phrase-triplebottom-line-heres-why-im-giving-up-on-it (accessed on 25 June 2018).

6. The Belgrade Charter Environmental Education. Available online: unesdoc.unesco.org/images/0001/ 000177/017772eb.pdf (accessed on 5 February 2018).

7. Tilbury, D. Environmental education for sustainability: Defining the New focus of Environmental Education in the 1990s. Environ. Educ. Res. 1995, 1, 195-212. [CrossRef]

8. Merrivan, N. Is the Mills for Collections or for People? Recent Developments on Increasing Opportunities in Access to Legumes in Great Britain. In New Approaches in Museology, Globalization and Localization; Economic and Social History Found Publishing: Istanbul, Turkey, 2000.

9. De Backer, F.; Peeters, J.; Kindekens, A.; Brosens, D.; Elias, W.; Lombaerts, K. Adult Visitors in Museum Learning Environments. Procedia Soc. Behav. Sci. 2015, 191, 152-162. [CrossRef]

10. Erdogan, M. The Effects of Ecology-Based Summer Nature Education Program on Primary School Students' Environmental Knowledge, Environmental Affect and Responsible Environmental Behavior. Educ. Sci. Theory Pract. 2011, 11, 2233-2237.

11. Aydede, M.N.; Savran, A. The Effect of Ecology-Based Nature Activities on Undergraduate Students' Scientific Progress Skills. Int. J. New Trends Arts Sports Sci. Educ. 2012, 1, 1-9.

12. Erdogan, M. The Effect of Summer Environmental Education Program (SEEP) on Elementary School Students' Environmental Literacy. Int. J. Environ. Sci. Educ. 2015, 10, 165-181.

13. Toshiya, K. Environmental Education in Formal Education in Japan. Jpn. J. Environ. Educ. 2017, 26, 21-26.

14. Burrow, A.K. Teaching Introductory Ecology with Problem-Based Learning. Bull. Ecol. Soc. Am. 2018, 99, 137-150. [CrossRef]

15. Korkmaz, M.; Fakir, H.; Alkan, H. Effects of Nature Training Projects on Environmental Perception and Attitudes. Appl. Ecol. Environ. Res. 2018, 16, 359-369. [CrossRef]

16. Shiang, L.R. A Research on Needs of Environmental Education Professional Competency and Development Required by Educators in Natural History Museums of Taiwan. Master's Thesis, Graduate Institute of Environmental Education, National Taiwan University Normal University, Taipei, Taiwan, 2006.

17. Zhou, R. Non-formal Environmental Education and Museum. Mus. Sci. Q. 1992, 6, 71-76.

18. Abacl, O.; Kamaraj, I. Museums as an Educational Medium: An Implementation Model. Procedia Soc. Behav. Sci. 2009, 1, 1337-1341. [CrossRef]

19. Fägerstam, E. High School Teachers' Experience of the Educational Potential of Outdoor Teaching and Learning. J. Adventure Educ. Outdoor Learn. 2014, 14, 56-81. [CrossRef]

20. Hovardas, T. Primary School Teachers and Outdoor Education: Varying Levels of Teacher Leadership in Informal Networks of Peers. J. Environ. Educ. 2016, 47, 237-254. [CrossRef]

21. Ayotte-Beaudet, J.P.; Potvin, P.; Lapierre, H.G.; Glackin, M. Teaching and Learning Science Outdoors in Schools' Immediate Surroundings at K-12 Levels: A Meta-Synthesis. Eurasia J. Math. Sci. Technol. Educ. 2017, 13, 5343-5363. [CrossRef]

22. Black, G. Transforming Museums in the 21st Century; Routledge: London, UK, 2011. 
23. Slater, A. Escaping to the Gallery: Understanding the Motivations of Visitors to Galleries. Int. J. Nonprofit Volunt. Sect. Mark. 2007, 12, 149-162. [CrossRef]

24. Crill, R. The Fabric of India; V \& A Publishing: London, UK, 2015.

25. Kemp, S. The Appreciative Eye of a Craftsman: Kipling as Curator and Collector at the Lahore Central Museum, 1875-93. In John Lockwood Kipling; Bryant, J., Weber, S., Eds.; Yale University Press: New York, NY, USA, 2017.

26. Caldin, R.; Dainese, R.; Panciroli, C. Didactics towards a Bottom-Up Museum Approach. Proceedings 2017, 1, 1108. [CrossRef]

27. Bishop, C. Radical Museology, Or, What's Contemporary in Museums of Contemporary Art? Koenig Books: London, UK, 2013.

28. Chao, R.F. Using Transformative Learning Theory to Explore the Mechanisms of Citizen Participation for Environmental Education on the Removal of Invasive Species: The Case of Green Island, Taiwan. EURASIA J. Math. Sci. Technol. Educ. 2017, 13, 2665-2682. [CrossRef]

29. Di Pietro, L.; Guglielmetti Mugion, R.; Renzi, M.F.; Toni, M. An audience-centric approach for museums sustainability. Sustainability 2014, 6, 5745-5762. [CrossRef]

30. Lucchi, E. Review of Preventive Conservation in Museum Buildings. J. Cult. Herit. 2018, 29, $180-193$. [CrossRef]

31. UNESCO and Sustainable Development Goals (UNESCO). Available online: https:/ / en.unesco.org/sdgs (accessed on 5 February 2018).

32. Meiselman, H.L. A Review of the Current State of Emotion Research in Product Development. Food Res. Int. 2015, 76, 192-199. [CrossRef]

33. Ryu, K.; Han, H. Influence of the Quality of Food, Service, and Physical Environment on Customer Satisfaction and Behavioral Intention in Quick-casual Restaurants: Moderating Role of Perceived Price. J. Hosp. Tour. Res. 2010, 34, 310-329. [CrossRef]

34. Lai, I.K.W. The Roles of Value, Satisfaction, and Commitment in the Effect of Service Quality on Customer Loyalty in Hong Kong-style Tea Restaurants. Cornell Hosp. Q. 2015, 56, 118-138. [CrossRef]

35. Chiou, S.C.; Wang, Y.C. The Example Application of Genetic Algorithms for the Framework of Cultural and Creative Brand Design in Tamsui Historical Museum. Soft Comput. 2018, 22, 2527-2545. [CrossRef]

36. Deming, W.E.; Edwards, D.W. Quality, Productivity, and Competitive Position; Massachusetts Institute of Technology, Center for Advanced Engineering Study: Cambridge, MA, USA, 1982; Volume 183.

37. Goetsch, D.L.; Davis, S. Introduction to Total Quality: Quality, Productivity, Competitiveness; Macmillan: New York, NY, USA, 1994.

38. Garvin, D.A. Managing Quality: The Strategic and Competitive Edge; The Free press: New York, NY, USA, 1988; pp. 251-309.

39. Juran, J.; Godfrey, A.B. Quality Handbook; McGraw-Hill: New York, NY, USA, 1999; pp. 173-178.

40. Kahle, L.R.; Close, A.G. (Eds.) Consumer Behavior Knowledge for Effective Sports and Event Marketing; Routledge: Abingdon/Oxford, UK, 2011.

41. New Taipei City Government Cultural Bureau. Available online: http://www.culture.ntpc.gov.tw/ (accessed on 5 October 2018).

42. The Tamsui Historical Museum of New Taipei City. Tamsui Treasure Hunt; Government of New Taipei City: New Taipei City, Taiwan, 2012.

43. Bureau of Cultural Heritage Ministry of Culture. Available online: https://www.boch.gov.tw/ (accessed on 5 October 2018).

44. Lükő, I.; Kollarics, T. The Significance of Environmental Sustainability in Adult Environmental Education. Int. J. Environ. Prot. 2013, 3, 1-9.

45. Ruso, L.; Topdal, E.B. The Use of Museums for Educational Purposes Using Drama method. Procedia Soc. Behav. Sci. 2014, 141, 628-632. [CrossRef]

46. Cong, L.C. A Formative Model of the Relationship between Destination Quality, Tourist Satisfaction and Intentional Loyalty: An Empirical Test in Vietnam. J. Hosp. Tour. Manag. 2016, 26, 50-62. [CrossRef]

47. Han, H.; Hyun, S.S. Key Factors Maximizing Art Museum Visitors' Satisfaction, Commitment, and Post-purchase Intentions. Asia Pac. J. Tour. Res. 2017, 22, 834-849. [CrossRef] 
48. Frangos, C.C.; Karapistolis, D.; Stalidis, G.; Constantinos, F.; Sotiropoulos, I.; Manolopoulos, I. Tourist Loyalty Is All About Prices, Culture and the Sun: A Multinomial Logistic Regression of Tourists Visiting Athens. Procedia Soc. Behav. Sci. 2015, 175, 32-38. [CrossRef]

49. Tasdemir, A.; Kus, Z.; Kartal, T. Out-of-the-school Learning Environments in Values Education: Science Centres and Museums. Procedia Soc. Behav. Sci. 2012, 46, 2765-2771. [CrossRef]

50. Han, H.; Hyun, S.S. Customer Retention in the Medical Tourism Industry: Impact of Quality, Satisfaction, Trust, and Price Reasonableness. Tour. Manag. 2015, 46, 20-29. [CrossRef]

51. Bbbbie, E. The Practice of Social Research; Wadsworth: Belmont, CA, USA, 2010.

52. Priyatno, D. SPSS 22 Pengolah Data Terpraktis; Penerbit ANDI: Yogyakarta, Indonesia, 2014.

53. Tamsui Historical Museum of New Taipei City. Available online: http://en.tshs.ntpc.gov.tw/ (accessed on 5 October 2018).

54. The World Conservation Union (IUCN); United Nations Environment Programme (UNEP); World Wide Fund for Nature (WWF). Caring for the Earth - A Strategy for Sustainable Living; Routledge: London, UK, 1991.

(C) 2018 by the authors. Licensee MDPI, Basel, Switzerland. This article is an open access article distributed under the terms and conditions of the Creative Commons Attribution (CC BY) license (http:/ / creativecommons.org/licenses/by/4.0/). 